\title{
Skin Cancers of the Auricle: A Retrospective Analysis of 41 Patients
}

\author{
Original Investigation $>\begin{aligned} & \text { Erdoğan Özgür }{ }^{1} \text { (D), Uğur Kamiloğlu² } \text { (D), Peyker Temiz }{ }^{3} \text { (D), Görkem Eskiizmir }{ }^{2} \text { (D) } \\ & \text { Department of Otorhinolaryngology, Muğla Sttkı Koçman University School of Medicine, Muğla, Turkey }\end{aligned}$ \\ ${ }^{2}$ Department of Otorhinolaryngology, Manisa Celal Bayar University School of Medicine, Manisa, Turkey \\ ${ }^{3}$ Department of Pathology, Manisa Celal Bayar University School of Medicine, Manisa, Turkey
}

Abstract

ORCID iDs of the authors: E.0. 0000-0002-5182-8831; U.K. 0000-0001-7257-7536; P.T. 0000-0001-6308-0157; G.E. 0000-0002-3125-8288.

Cite this article as: Özgür E, Kamiloğlu U, Temiz P, Eskiizmir G. Skin Cancers of the Auricle: A Retrospective Analysis of 41 Patients. Turk Arch Otorhinolaryngol 2020; 58(3): 169-73.

\section{Corresponding Author:}

Erdoğan Özgür, erdoganozgur@mu.edu.tr

Received Date: 20.06.2020 Accepted Date: 31.07 .2020

Content of this journal is licensed under a Creative Commons Attribution 4.0 International License. Available online at www.turkarchotolaryngol.net
Objective: Skin cancers of the auricle usually present with challenges because of the unique anatomy and topography of the auricle and the behavior of the tumor. The purpose of this study was to evaluate the clinical and histopathological characteristics and the surgical outcomes in patients with skin cancer of the auricle.

Methods: Medical records of patients who underwent surgery for a skin cancer of the auricle at two different tertiary medical centers during 2010 to 2020 were reviewed retrospectively. Sociodemographic data of patients, tumor location and size, histopathological type and subtype, T-stage, recurrence, and reconstructive technique were evaluated.

Results: The study included 41 patients with skin cancers of the auricle. Thirty-six (87.8\%) were male and five $(12.2 \%)$ were female; with a male-to-female ratio of $7.2: 1$. The mean age of the patients was 71.4
(46-92) years. Eighteen (43.9\%) tumors were basal cell carcinoma (BCC) and $17(41.5 \%)$ tumors were cutaneous squamous cell carcinoma (cSCC). The most common subunit for tumor location was the helix ( $n=17,41.5 \%)$. Wedge resection plus primary closure was the most common surgical technique (58.5\%). Recurrent disease was detected in five patients (12.1\%).

Conclusion: The frequency of the skin cancers of the auricle was remarkably high in men, and the helix was the most common subunit. Both BCC and cSCC were the most common histopathological types. Poor prognostic factors such as lymph node metastasis, perineural invasion, and recurrence were relatively common in patients with $\mathrm{cSCC}$ of the auricle.

Keywords: Neoplasms of ear auricle, reconstructive surgical procedure, skin neoplasms, ear auricle

\section{Introduction}

Skin cancer is the most frequent cancer type in the white population, and its frequency is increasing day by day. The head and neck region is the predominant location for skin cancers with a ratio of up to $90 \%(1-3)$. Skin cancers of the auricle account for approximately $6-10 \%$ of all cutaneous malignancies found in the head and neck region $(1,4)$. Basal cell carcinoma (BCC) and cutaneous squamous cell carcinoma (cSCC) constitute a significant portion of the cancers localized to this region. Rarely, other histopathological types may also be detected like malignant melanoma, Merkel cell carcinoma, Kaposi's sarcoma, dermatofibrosarcoma (5). BCC is a locally invasive skin cancer that rarely metastasizes. On the other hand, cSCC has an infiltrative growth pattern and a relatively high tendency to metastasize (6). Ultraviolet radiation and environmental factors are the leading risk factors for skin cancers. Skin scars, burns, ulcers, immunosuppression, previous radiotherapy, chemical agent exposure, and human papillomavirus infection are the other risk factors $(7,8)$.

The auricle has a unique anatomic structure with intricate architecture. It has an essential role in the aesthetic balance of the face. Moreover, the auricle is a unit located in the H-zone of the face (Mask Area). Therefore, tumors located on the auricle are considered as "high-risk" tumors (9-11). Additionally, skin cancers of the auricle have a higher risk of invasion and of metastasis when compared with 
the other sun-exposed regions (6). Presently there are a variety of treatment options for skin cancers, which mainly are classified as surgical and non-surgical. Surgery should be the first-line treatment since skin cancers located on the auricle are in the high-risk group. However, the anatomical and structural features of the auricle pose challenges for oncological and reconstructive surgeries. Therefore, the purpose of this study was to evaluate the clinicopathological features, the surgical results, and the reconstructive techniques used in patients with skin cancers of the auricle.

\section{Methods}

The study was approved by Human Researches Ethics Committee of Muğla Sıtkı Koçman University (Approval Date: April 29, 2020; Approval Number: 55). The study included the patients with skin cancers of the auricle who underwent surgery during 2010 to 2020 in Muğla S1tk1 Koçman University, Department of Otolaryngology-Head and Neck Surgery, and Manisa Celal Bayar University, Department of Otolaryngology-Head and Neck Surgery. Patients were included if their complete medical records were available, and their sociodemographic data (age and gender), tumor location (left or right side) and subunit (helix, antihelix, cymba concha, lobule, or more than one subunit), tumor size, histopathological type and subtype, $\mathrm{T}$-stage, recurrence, and reconstructive technique were evaluated and recorded.

\section{Statistical Analysis}

All statistical analyses were performed using the Statistical Package for Social Sciences version 17.0 for Windows (SPSS Inc.; Chicago, IL, USA). Descriptive data were retrieved as minimum, maximum, mean, standard deviation, number, and percentage.

\section{Results}

Of the 41 patients included in the study, 36 (87.8\%) were male and $5(12.2 \%)$ were female. The male-to-female ratio was 7.2:1. The ages of patients ranged from 46 to 92 years (mean age was $71.4 \pm 11.05$ years). Tumors were on the left auricle in $68.3 \%$ of the patients. More than half of the tumors were located on the helix $(n=17,41.5 \%)$ or the cymba concha $(n=7,17.1 \%)$. Nine cases $(22 \%)$ had tumors that involved multiple subunits. Histopathologically, 18 (43.9\%) tumors were BCC, and 17 (41.5\%) were cSCC. Other tumors were basosquamous carcinoma, malignant melanoma, Merkel cell carcinoma, and apocrine carcinoma. The distribution of tumor locations and histopathological subtypes are given in Table 1.

Tumor sizes were found similar when compared according to the histopathological types of skin cancers. The mean tumor size

\section{Main Points}

- The helix is the most common location for the skin cancers of the auricle.

- Skin cancers of the auricle are more common in men.

- As the auricles are located in the $\mathrm{H}$-zone of the face, recurrence rates are relatively high for skin cancers except for BCC. was $2.19 \pm 1.81 \mathrm{~cm}$ in patients with $\mathrm{cSCC}$ and $2.20 \pm 1.39 \mathrm{~cm}$ in patients with BCC. In most of the cases (53.6\%) the tumors were stage 1 ; particularly in $72.2 \%$ of the BCC cases. On the other hand, in $51.6 \%$ of the patients with cSCC the tumor was stage 2 or higher. Five patients had lymph node metastasis at the time of diagnosis, and perineural invasion was detected in two cases. Recurrent disease was observed in five cases (three $\mathrm{pa}^{-}$ tients with $\mathrm{cSCC}$, one patient with BCC, and one patient with Merkel cell carcinoma). One patient with Merkel cell carcinoma died because of cancer progression and distant metastases.

The most frequently used surgical technique was wedge resection plus primary closure (58.5\%). Full-thickness grafting was preferred in tumors located on the cymba concha. Pivotal flaps were used in four patients, although staged-surgery was necessary (Figure 1). Partial or total auriculectomy was performed in patients with larger tumors. The distribution of the reconstructive techniques according to tumor location given in Table 2 .

In our study, the vast majority of the patients with skin cancer of the auricle were stage 1 . Most of the patients in stage 1 had $\mathrm{BCC}$, whereas the majority of the patients in stage $2 \mathrm{cSCC}$. Additionally, regional metastasis and locoregional recurrence were most frequent in patients with cSCC (Table 3).

\section{Discussion}

Skin cancer is the most common cancer type and affects millions of people worldwide every year. The location of the skin cancer is one of the most significant risk factors that affects the treatment outcome. Skin cancers usually develop in sun-exposed areas, especially in the head and neck region (12). Among skin cancers of the head and neck region, nasal, nasolabial, periorbital, auricular and temporal units are the high-risk locations of the face (9-11). Recurrence rate is higher in these regions, which are also called the "H-zone" or the "mask area," and have functional and cosmetic importance. Skin cancers of the $\mathrm{H}-\mathrm{zo}^{-}$ ne, when compared with the other parts of the face, are in the "high-risk" group irrespective of tumor size.

Skin cancers generally develop in the elderly population. In our study, the mean age of patients was $71.4 \pm 11.05$ years. Similarly, Ragi et al. (13) reported a mean age of 71.8 years in their clinical study. The main reason why the disease is more common among the elderly is their cumulative sun exposure over the years. Moreover, skin cancers of the auricle are predominantly seen in men. In our study, the gender ratio was 7.2:1 favoring male patients. In the literature, a higher ratio of approximately $30: 1$ was reported $(14,15)$. Despite the lack of evidence for the pathophysiological mechanisms, some suggest that women, compared to men, are generally exposed to lower cumulative Ultraviolet-B doses on their auricles since their longer hair covering the ears has a protective effect and/ or women tend to make more use of sun-protective clothing or accessories. In our study, skin cancers of the auricle were more common on the left side than on the right side (ratio, 2.15:1). Some authors suggested that the reason why the condition is more common among men and on the left auricle could be 
Table 1. Histopathological types and subunits of the skin cancers located on the auricle

\begin{tabular}{|c|c|c|c|c|c|c|c|}
\hline \multirow[b]{2}{*}{ Subunit } & \multicolumn{3}{|c|}{$\operatorname{BCC}(n=18)$} & \multirow[b]{2}{*}{ Basosquamous $n=1$} & \multirow[b]{2}{*}{$\mathrm{cSCC} \mathrm{n}=17$} & \multirow[b]{2}{*}{ Other $n=5$} & \multirow[b]{2}{*}{ Total $n=41 n(\%)$} \\
\hline & Nodular $\mathrm{n}=11^{*}$ & Infiltrative $n=8^{*}$ & Superficial $n=1$ & & & & \\
\hline Helix & 4 & 3 & 1 & - & 7 & 1 & $17(41.5)$ \\
\hline Cymba concha & 4 & 2 & - & - & 2 & 1 & $7(17.1)$ \\
\hline Lobule & 1 & - & - & - & 2 & 2 & $4(9.8)$ \\
\hline Tragus & 1 & 0 & - & - & 1 & - & $2(4.9)$ \\
\hline Postauricular & - & 2 & - & - & - & - & $2(4.9)$ \\
\hline More than one subunit & 1 & 1 & - & 1 & 5 & 1 & $9(22.0)$ \\
\hline
\end{tabular}

*The histopathological type of two cases were reported as both nodular and infiltrative pattern BCC: basal cell carcinoma; cSCC: cutaneous squamous cell carcinoma

Table 2. Distribution of oncological and reconstructive surgeries by tumor location

\begin{tabular}{|c|c|c|c|c|c|c|c|}
\hline \multirow[b]{2}{*}{ Surgical procedure } & \multicolumn{6}{|c|}{ Tumor location } & \multirow[b]{2}{*}{$\mathrm{n}(\%)$} \\
\hline & Helix & Cymba concha & Lobule & Tragus & Postauricular & More than one subunit & \\
\hline Wedge resection plus primary closure & 13 & 2 & 1 & 2 & - & 6 & $24(58.5)$ \\
\hline Full-thickness grafting & - & 4 & - & - & - & 4 & $6(14.6)$ \\
\hline Pivotal flaps & 2 & 1 & - & - & 1 & - & $4(9.8)$ \\
\hline Partial auriculectomy & 2 & - & 3 & - & - & - & $5(12.2)$ \\
\hline Total auriculectomy & - & - & - & - & 1 & 1 & $2(4.9)$ \\
\hline
\end{tabular}

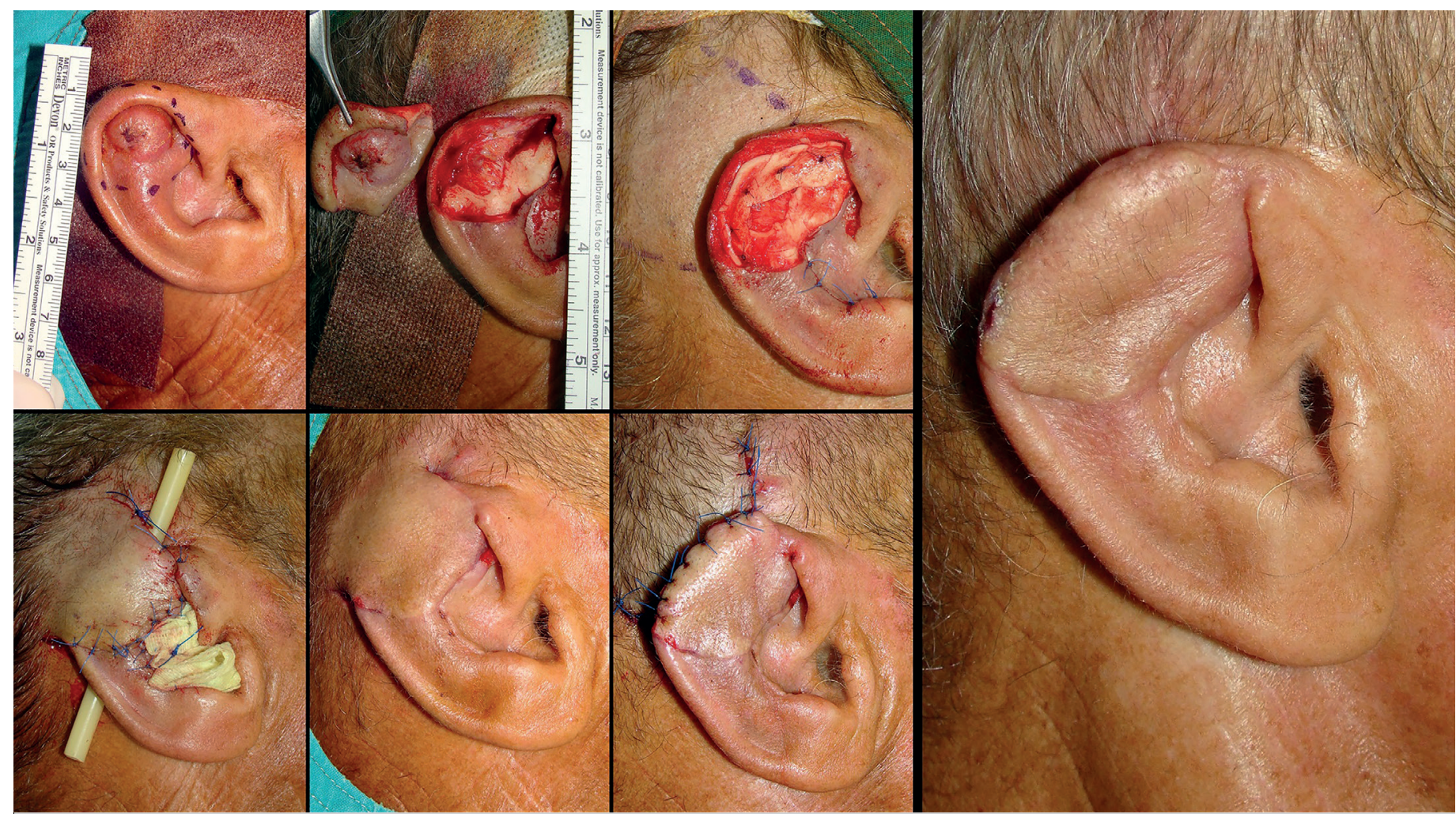

Figure 1. Reconstruction of the defect due to a nodular type BCC excision in the upper 1/3 part of the auricle with staged retroauricular pivotal flap technique

associated with the seating position while driving, where the left ear has a higher chance of sun-exposure (16). Additionally, skin cancers of the auricle were most frequently identified on the helix (the most sun-exposed area), the cymba concha, and on more than one subunit.
In skin cancers, the primary goal of surgery should be the complete removal of the cancerous tissue with clear margins and provision of a maximal functional and cosmetic outcome. Additionally, close or narrow surgical margins are associated with increased risk of recurrence. Our results demonstrated that 
Table 3. Distribution of staging and the prognostic features of the tumors by histopathological type

\begin{tabular}{l|l|c|c|c|c}
\hline \multicolumn{2}{l|}{} & BCC & cSCC & Basosquamous & Other \\
\hline \multirow{2}{*}{ T-stage } & T cis & 1 & 1 & - \\
\cline { 2 - 5 } & T1 & 13 & 7 & - \\
\cline { 2 - 5 } & T2 & 3 & 9 & 1 \\
\cline { 2 - 5 } & T3-T4 & 1 & - & - \\
\hline Lymph node involvement & & - & 4 & - \\
\hline Recurrence & & 1 & 3 & - \\
\hline Perineural invasion & & 1 & - & 1 \\
\hline
\end{tabular}

BCC: basal cell carcinoma; cSCC: cutaneous squamous cell carcinoma

wedge resection plus primary closure are the most common reconstructive technique used in tumors located at the helix. Skin grafting was more commonly used in tumors located at the cymba concha. Finally, partial or total auriculectomy was predominantly preferred in patients with large tumors or tumors that involved more than one subunit.

In skin cancers of the head and neck, the ratio of $\mathrm{BCC}$ to $\mathrm{cSCC}$ is approximately 3 to 4:1 (17). However, the frequencies of $\mathrm{BCC}$ and $\mathrm{cSCC}$ were similar in patients with skin cancers of the auricle (17). Other studies reported that $\mathrm{cSCC}$ was more frequent on the auricle $(13,18)$. In our study, the frequencies of BCC and cSCC were comparable (43.9\% vs $41.5 \%$ ). Presently, it is well-known that both BCC and cSCC generally have more aggressive behavior when localized to the auricle, irrespective of their histopathological types $(13,18)$. Jarell and Mully (19) reported that BCC on the auricle had a more aggressive phenotype compared to those in the other sites of the body. Since the auricle is a highly visible unit of the face, most of the tumors are generally detected at an early stage. In our study, more than half of the patients with cSCC were T2. Similarly, Gustaityte-Larsen and Illum (15) reported that the majority of their patients with cSCC of the auricle were T2 or higher. Notably, the risk of lymph node metastasis rises as the size of the tumor increases. Moreover, the risk of recurrence is relatively high in patients with $\mathrm{cSCC}$ of the auricle and lymph node involvement that also has a dismal prognosis $(10,20,21)$. Clinical studies showed that patients with cSCC of the head and neck and lymph node involvement could have recurrence rates at $28-33 \%(22-24)$. In our study, five of patients with cSCC had lymph node involvement at the time of diagnosis, and three of these cases had locoregional recurrence.

\section{Conclusion}

In this study, the helix was the most common subunit for the skin cancer of the auricle. The frequency of the skin cancer of the auricle was predominantly high in men. The most common histopathological types were $\mathrm{BCC}$ and $\mathrm{cSCC}$. Poor prognostic factors such as lymph node metastasis, perineural invasion, and recurrence were relatively common in patients with $\mathrm{cSCC}$ of the auricle. To conclude, it is worth noting that the management of skin cancers of the auricle generally bears challenges because of its unique anatomy and topography, as well as surgical risks and recurrence risks in the elderly population.

Ethics Committee Approval: Ethics committee approval was received for this study from the Human Researches Ethics Committee of Muğla Sitkı Koçman University (Approval Date: April 29, 2020; Approval Number: 55).

Informed Consent: Informed consent was not obtained due to the nature of the study.

Peer-review: Externally peer-reviewed.

Author Contributions: Concept - E.Ö., G.E.; Design - E.Ö., G.E.; Supervision - G.E., P.T.; Materials - E.Ö., G.E., U.K., P.T.; Data Collection and/or Processing - E.Ö., U.K.; Analysis and/or Interpretation - E.Ö., U.K., P.T.; Literature Search - E.Ö., U.K.; Writing - E.Ö., U.K., G.E.; Critical Reviews - E.Ö., G.E., P.T.

Conflict of Interest: The authors have no conflicts of interest to declare.

Financial Disclosure: The authors declared that this study has received no financial support.

\section{References}

1. Eisemann N, Waldmann A, Geller AC, Weinstock MA, Volkmer $B$, Greinert R, et al. Non-melanoma skin cancer incidence and impact of skin cancer screening on incidence. J Invest Dermatol 2014; 134: 43-50. [Crossref]

2. Leiter U, Eigentler T, Garbe C. Epidemiology of Skin Cancer. In: Reichrath J, editor. Sunlight, Vitamin D and Skin Cancer. New York, NY: Springer; 2014.p.120-40. [Crossref]

3. McGuire JF, Ge NN, Dyson S. Nonmelanoma skin cancer of the head and neck I: histopathology and clinical behavior. Am J Otolaryngol. 2009; 30: 121-33. [Crossref]

4. Arons MS, Savin RC. Auricular cancer. Some surgical and pathologic considerations. Am J Surg 1971; 122: 770-6. [Crossref]

5. Apalla Z, Lallas A, Sotiriou E, Lazaridou E, Ioannides D. Epidemiological trends in skin cancer. Dermatol Pract Concept 2017; 7 : 1-6. [Crossref]

6. Brantsch KD, Meisner C, Schonfisch B, Trilling B, Wehner-Caroli J, Rocken M, et al. Analysis of risk factors determining prognosis of cutaneous squamous-cell carcinoma: a prospective study. Lancet Oncol 2008; 9: 713-20. [Crossref] 
7. Gallagher RP, Hill GB, Bajdik CD, Fincham S, Coldman AJ, McLean DI, et al. Sunlight exposure, pigmentary factors, and risk of nonmelanocytic skin cancer. I. Basal cell carcinoma. Arch Dermatol 1995; 131: 157-63. [Crossref]

8. Madan V, Lear JT, Szeimies RM. Non-melanoma skin cancer. Lancet 2010; 375: 673-85. [Crossref]

9. Fattahi TT. An overview of facial aesthetic units. Journal of Oral and Maxillofacial Surgery 2003; 61: 1207-11. [Crossref]

10. Rowe DE, Carroll RJ, Day CL, Jr. Prognostic factors for local recurrence, metastasis, and survival rates in squamous cell carcinoma of the skin, ear, and lip. Implications for treatment modality selection. J Am Acad Dermatol 1992; 26: 976-90. [Crossref]

11. Veness MJ. Defining patients with high-risk cutaneous squamous cell carcinoma. Australas J Dermatol 2006; 47: 28-33. [Crossref]

12. Narayanan DL, Saladi RN, Fox JL. Ultraviolet radiation and skin cancer. Int J Dermatol 2010; 49: 978-86. [Crossref]

13. Ragi JM, Patel D, Masud A, Rao BK. Nonmelanoma skin cancer of the ear: frequency, patients' knowledge, and photoprotection practices. Dermatol Surg 2010; 36: 1232-9. [Crossref]

14. Mulvaney PM, Higgins HW, 2nd, Dufresne RG, Jr., Cruz AP, Lee KC. Basal cell carcinomas of the ear are more aggressive than on other head and neck locations. J Am Acad Dermatol 2014; 70 : 924-6. [Crossref]

15. Gustaityte-Larsen D, Illum P. Non-melanoma skin cancer of the auricle is treated according to national guidelines. Dan Med J 2013; 60: A4587.

16. Kim DP, Chabra I, Chabra P, Jones EC. Sunscreen use while driving. J Am Acad Dermatol 2013; 68: 952-6. [Crossref]
17. Marks R. An overview of skin cancers. Incidence and causation. Cancer 1995; 75: 607-12. [Crossref]

18. Ahmad I, Das Gupta AR. Epidemiology of basal cell carcinoma and squamous cell carcinoma of the pinna. J Laryngol Otol 2001; 115: 85-6. [Crossref]

19. Jarell AD, Mully TW. Basal cell carcinoma on the ear is more likely to be of an aggressive phenotype in both men and women. J Am Acad Dermatol 2012; 66: 780-4. [Crossref]

20. Kyrgidis A, Tzellos TG, Kechagias N, Patrikidou A, Xirou P, Kitikidou K, et al. Cutaneous squamous cell carcinoma (SCC) of the head and neck: risk factors of overall and recurrence-free survival. Eur J Cancer 2010; 46: 1563-72. [Crossref]

21. Rodriguez-Vigil T, Vazquez-Lopez F, Perez-Oliva N. Recurrence rates of primary basal cell carcinoma in facial risk areas treated with curettage and electrodesiccation. J Am Acad Dermatol 2007; 56: 91-5. [Crossref]

22. Andruchow JL, Veness MJ, Morgan GJ, Gao K, Clifford A, Shannon KF, et al. Implications for clinical staging of metastatic cutaneous squamous carcinoma of the head and neck based on a multicenter study of treatment outcomes. Cancer 2006; 106: 1078-83. [Crossref]

23. Magnano M, De Stefani A, Lerda W, Usai A, Ragona R, Bussi $\mathrm{M}$, et al. Prognostic factors of cervical lymph node metastasis in head and neck squamous cell carcinoma. Tumori 1997; 83: 922-6. [Crossref]

24. Mullen JT, Feng L, Xing Y, Mansfield PF, Gershenwald JE, Lee $\mathrm{JE}$, et al. Invasive squamous cell carcinoma of the skin: defining a high-risk group. Ann Surg Oncol 2006; 13: 902-9. [Crossref] 